\title{
Effect of Conservation Trenches on Plantation Crop in Degraded Watershed in Kandhamal District of Odisha
}

\section{Subudhi $\mathbf{R}^{\star}$}

Department of Soil and Water Conservation Engineering, College of Agricultural Engineering and Technology, Orissa University of Agriculture and Technology, Bhubaneswar, Odisha, India

\begin{abstract}
Kandhamal district situated in central part of Orissa receives an annual rainfall of $1396 \mathrm{~mm}$, and this region is highly prone to soil and runoff loss due to heavy rainfall during kharif. A trial was conducted during 2001-2004 to study the effect of conservation trenches on plantation crop. This trial was conducted on farmers' field of Sudreju village of Kandhamal district under National Agricultural Technology Project (NATP, RRPS-7), with the following objectives.

1. To conserve moisture for establishment of plantation crop

2. To reduce erosion from upstream area.

3. To increase production of timber, fruit species, fuel wood and fodder. The following treatments were tried.

a. No treatment (Control) b. Continuous V-ditches at $10 \mathrm{~m}$ horizontal interval. c. Continuous V-ditches at $20 \mathrm{~m}$ horizontal interval. d. V-ditches staggered at $5 \mathrm{~m}$ horizontal interval. e. V-ditches staggered at $10 \mathrm{~m}$ horizontal interval. Mango varieties Pusa Amrapalli was tried during kharif and during, rabi Black gram (PU-30) was tried in between mango rows. It is observed that in, cont. contour V-ditch at $10 \mathrm{~m}$ interval rate of growth was $2.06 \mathrm{~cm} / \mathrm{month}$ in case of Amrapalli,which is $46 \%$ higher compared to control. The grain yield of niger, black gram and mustard are $33.4 \%, 23.5 \%$ and $26.6 \%$ higher than control, respectively. Though the cost of construction is little high, it is recommended to practice contour V-ditch at $10 \mathrm{~m}$ intervals, to conserve soil and moisture, and to get more grain yield in degraded watershed of Kandhamal district.
\end{abstract}

Keywords: Conservation trenches; Plantation crop

\section{Introduction}

Kandhamal, though receives rainfall around $1396 \mathrm{~mm}$, due to its uneven distribution, heavy downpour of rain at times results in sudden high runoff, which ultimately causes substantial soil loss. The uneven distribution of rainwater and movement of soil within the watershed, results heavy loss to farmers. So conservation trenches for plantation crops helps to conserve the soil and moisture, and ultimately improves grain yield of the farmers. The objectives of the experiment are to conserve moisture for establishment of plantation crop, to reduce soil erosion from upstream area, and to increase production of timber, fruit species, fuel wood and fodder.

Samra JS [1] reported that renovation of terrace and plantation of fruit plants, timber plants improved biomass production, net returns, growth of crop, productivity, reduction of runoff in the range of 1.510.8 times, peak flow rate by 20 times and soil loss in the range of 1.2 to 5.2 times, as well as water table rise. Subudhi et al. [2] have reported that effect of vegetative barrier like Vetiver has increased the rice yield, decreased the soil loss and decreased the runoff compared to farmers practice. Arora and Gupta [3] reported that there is a growing need for rain water management, since $96 \mathrm{~m}$ ha out of $142 \mathrm{~m}$ ha of net cultivated land of the country is rain fed. Scientific use of these resources will definitely increase the productivity and conservation of resources like soil and water. Kumar [4] reported that impact of different soil and water conservation techniques viz. contour bunding,terracing, land leveling, smoothening and gully plugging, sowing across the slope, vegetative barrier, increase the Kharif crops by $25-30 \%$. Establishment of vegetative barrier with mechanical measures were more effective in controlling soil erosion $\left(3.8 \mathrm{tha}^{-1}\right)$ over conventional method $\left(9.64 \mathrm{t} \mathrm{ha}^{-1}\right)$, and runoff thereby making more moisture available for crop growth. Anonymous [5] reported that V-ditch at $10 \mathrm{~m}$ CCVD increased the crop yield significantly compared to no treatment.

\section{Materials and Methods}

The study area lies in the Pila-Salki Watershed of Mahanadi Catchment. It falls under Sudreju revenue village of Khajuripada block in Phulbani district. As per Soil Conservation Department Govt. of Orissa, it is a part of watershed ORM 3-9-6-5. As per watershed map classification reported by the Orissa Remote Sensing Application Center (Department of Science and Technology, Govt. Of Orissa), the selected Micro-Watershed falls under Sub-Watershed No 1707-31-01-01. This sub-watershed consists of parts of Survey of India Topographical Sheet Nos. 73D/2, 73D/6, 73D/3 and 73D/7. However, the Micro-Watershed under study falls only under Topo Sheet No. 73D/6. These Micro-Watersheds are located at a distance of about 10 $\mathrm{km}$ from Phulbani district headquarters on Phulbani-Sudrukumpa State Highway. An on farm trial was conducted in the year 2001-2004, at Sudreju under Dry land Agril Research Project, Orissa University of Agriculture and Technology, Phulbani, financed through National Agriculture Technology Project, Rain fed Rice Production System-7. Five following treatments were tested with 4 replication in randomized block design.

*Corresponding author: Subudhi R, Associate Professor, Department of Soil and Water Conservation Engineering, College of Agricultural Engineering and Technology, Orissa University of Agriculture and Technology, Bhubaneswar, Odisha, India, E-mail: rsubudhi5906@gmail.com

Received July 27, 2013; Accepted August 20, 2013; Published August 25, 2013

Citation: Subudhi R (2013) Effect of Conservation Trenches on Plantation Crop in Degraded Watershed in Kandhamal District of Odisha. Agrotechnol 2: 112 doi:10.4172/2168-9881.1000112

Copyright: ( $) 2013$ Subudhi R. This is an open-access article distributed under the terms of the Creative Commons Attribution License, which permits unrestricted use, distribution, and reproduction in any medium, provided the original author and source are credited. 
Citation: Subudhi R (2013) Effect of Conservation Trenches on Plantation Crop in Degraded Watershed in Kandhamal District of Odisha. Agrotechnol 2: 112. doi:10.4172/2168-9881.1000112

Page 2 of 3

\section{Treatments}

T1-No treatment; T2-Continuous V-ditches at $10 \mathrm{~m}$ horizontal intervals; T3-Continuous V-ditches at $20 \mathrm{~m}$ horizontal intervals; T4-Vditches staggered at $5 \mathrm{~m}$ horizontal interval; T5-V- ditches staggered at $10 \mathrm{~m}$ horizontal intervals.

The name of farmer is Kisore Pradhan. Mango variety Amrapalli was tried during Kharif in 5 meter spacing and Niger, Black gram and Mustard were tried during Rabi with $30 \mathrm{~cm}$ spacing. Weather was favorable for all crops (Table 1).

\section{Disease and pest}

Mango hopper in all Mango varieties. Crop stand: Good. Slope: Field was contour surveyed, and the slope was $4.15 \%$. Soil loss was measured after the rainy season in the V-ditches; the soil was completely filled in $10 \mathrm{~m}$ CCVD. So soil conserved was calculated as we know the size of the $\mathrm{V}$-ditch before and after the rainy season.

\section{Results and Discussion}

Monthly rainfall is presented in Table 2. It is observed from above table that the year 2002 is a drought years, it received only $74 \%$ of rainfall, a deficit of 36\% from mean rainfall. But 2001 and 2003 are

\begin{tabular}{|c|c|c|c|c|c|c|c|}
\hline SI.No. & $\begin{array}{l}\text { Name of the } \\
\text { farmer }\end{array}$ & $\begin{array}{l}\text { Depth } \\
\text { (cm) }\end{array}$ & Crop & $\begin{array}{l}\text { pH } \\
(1: 2.5)\end{array}$ & $\begin{array}{l}\mathrm{EC} \\
\left(\mathrm{dsm} \mathrm{m}^{-1}\right) \\
\mathrm{q}\end{array}$ & $\begin{array}{l}\text { OC } \\
\text { (g/kg) }\end{array}$ & $\begin{array}{l}\text { OM } \\
(\mathrm{g} / \mathrm{kg})\end{array}$ \\
\hline 1 & Kishore Pradhan & $0-30$ & Mango & 5.42 & 0.0174 & 5.62 & 9.67 \\
\hline 2 & Kishore Pradhan & $30-60$ & Mango & 5.98 & 0.042 & 3.26 & 5.61 \\
\hline
\end{tabular}

Table 1: Soil analysis report. good years receiving $39.6 \%$ and $4 \%$ more than the mean annual rainfall, respectively. The mean annual rainfall is $1396.14 \mathrm{~mm}$. The fluctuation shows the rainfall is very erratic in all the three years.

Table 3 shows rate of growth of mango. The rate of growth is highest $(3.02 \mathrm{~cm} / \mathrm{month})$ in T2-CCVD at 10 meter interval, and lowest $(1.22$ $\mathrm{cm} / \mathrm{month}$ ) in control from 2001-2003. The grain yield of Niger, black gram and mustard are $33.4 \%, 23.5 \%$ and $26.6 \%$ higher than control, respectively (Table 3 ). This may be due to more soil and water conserved at root zone of the crop as the moisture content in T2 is more compared to all other treatments and lowest in control, as there was no V-ditch (Table 3). The soil conserved in T2 is 6.2 ton/ha, followed by T5 where soil conserved was $5.5 \mathrm{t} / \mathrm{ha}$. Patil et al. [6] has obtained similar result, they got lowest soil loss $(1.51 \mathrm{t} / \mathrm{ha})$ and highest survival percentage of cashew nut plantation in Continuous contour trench compared to staggered trench (3.95 t/ha) and control (16.55 t/ha). So it can be concluded that $10 \mathrm{~m}$ CCVD should be recommended for uplands of degraded watershed at Kandhamal district of Orissa.

\section{Summary and Conclusion}

The present study reveals that grain yield of niger, black gram and mustard are $33.4 \%, 23.5 \%$ and $26.6 \%$ higher than control, respectively. Though the cost of construction is little high, it is recommended to practice contour $\mathrm{V}$-ditch at $10 \mathrm{~m}$ intervals, to conserve soil and moisture, and to get more grain yield in degraded watershed of Kandhamal district. It is observed that in cont. contour V-ditch at $10 \mathrm{~m}$ interval rate of growth was $3.02 \mathrm{~cm} / \mathrm{month}$ in case of Amrapalli, which is $46 \%$ higher, compared to control. Also, we can conserve $6.2 \mathrm{t} / \mathrm{ha}$ of soil by $10 \mathrm{sm}$ CCVD, which is highest among all the treatments.

\begin{tabular}{|c|c|c|c|c|c|c|c|}
\hline Month & $\begin{array}{l}\text { Monthly } \\
\text { normal }\end{array}$ & $\begin{array}{l}\text { Actual } \\
\text { in } 2001\end{array}$ & $\begin{array}{l}\text { Deviation from } \\
\text { normal, \% }\end{array}$ & Actual in 2002 & $\begin{array}{l}\text { Deviation from } \\
\text { normal, \% }\end{array}$ & Actual in 2003 & $\begin{array}{l}\text { Deviation from } \\
\text { normal, \% }\end{array}$ \\
\hline January & 9.18 & - & -100 & 13.0 & +41.6 & 0.0 & -100 \\
\hline February & 14.07 & - & -100 & - & -100 & 23.5 & +67.0 \\
\hline March & 21.70 & 56.0 & +158.1 & 20.0 & -7.8 & 12.5 & -57.6 \\
\hline April & 30.40 & - & -100 & 32.0 & +5.2 & 89.0 & +192.7 \\
\hline May & 57.48 & 48.0 & -16.5 & 70.0 & +21.8 & 7.0 & -87.8 \\
\hline June & 191.62 & 504.9 & +163.5 & 149.0 & -22.2 & 117.0 & -38.9 \\
\hline July & 353.62 & 797.6 & +125.6 & 129.0 & -63.5 & 237.0 & -33.0 \\
\hline August & 378.65 & 300.1 & -20.7 & 329.0 & -13.1 & 358.1 & -5.4 \\
\hline September & 218.57 & 124.7 & -42.9 & 134.9 & -38.3 & 350.1 & +60.2 \\
\hline October & 88.93 & 111.5 & +25.4 & 11.0 & -87.6 & 216.0 & +142.9 \\
\hline November & 27.48 & 6.9 & -74.9 & - & -100 & 0.0 & -100 \\
\hline December & 4.45 & - & -100 & - & -100 & 42.0 & -843.8 \\
\hline Annual & 1396.15 & 1949.7 & +39.6 & 887.9 & -36.4 & 1452.2 & +4.0 \\
\hline
\end{tabular}

Soil: The soil data has been presented in Table 2 it reveals that $\mathrm{pH}$ is low in top soil (5.42), compared to bottom soil (5.98)

Table 2: Monthly rainfall (mm) during 2001, 2002 and 2003 and their deviation from mean.

\begin{tabular}{|c|c|c|c|c|c|c|}
\hline Treatments & $\begin{array}{l}\text { Niger (q/ha) } \\
(2001-02)\end{array}$ & $\begin{array}{l}\text { Black gram } \\
\text { (q/ha) (2002-03) }\end{array}$ & $\begin{array}{l}\text { Mustard(q/ha) } \\
(2003-04)\end{array}$ & $\begin{array}{l}\text { Mean moisture Content (\%) } \\
\text { At } 0-30 \mathrm{~cm} \text { on weight basis } \\
\text { during } 2001-03\end{array}$ & $\begin{array}{l}\text { Mean rate of growth } \\
\text { of mango (cm/month) } \\
\text { during } 2001-2003\end{array}$ & $\begin{array}{l}\text { Mean Soil } \\
\text { conserved in ton/ha }\end{array}$ \\
\hline T1-No treatment & 2.33 & 6.12 & 4.17 & 3.67 & 1.22 & 0 \\
\hline $\begin{array}{l}\text { T2-Continuous V-ditches at } 10 \mathrm{~m} \\
\text { horizontal interval. }\end{array}$ & 3.11 & 8.00 & 5.28 & 10.25 & 3.02 & 6.2 \\
\hline $\begin{array}{l}\text { T3-Continuous V-ditches at } 20 \mathrm{~m} \\
\text { horizontal interval. }\end{array}$ & 2.44 & 7.12 & 4.85 & 5.59 & 2.47 & 3.2 \\
\hline $\begin{array}{l}\text { T4-V-ditches staggered at } 5 \mathrm{~m} \\
\text { horizontal interval. }\end{array}$ & 2.51 & 7.37 & 5.15 & 8.47 & 2.42 & 5.5 \\
\hline $\begin{array}{l}\text { T5-V- ditches staggered at } 10 \mathrm{~m} \\
\text { horizontal intervals. }\end{array}$ & 2.49 & 7.25 & 5.00 & 7.02 & 2.50 & 3.1 \\
\hline $\mathrm{SE}(\mathrm{m})+$ & 0.13 & 0.57 & 0.05 & & & \\
\hline CD (0.05) & 0.39 & NS & 0.17 & & & \\
\hline
\end{tabular}

Table 3: Yield, plant height and moisture content and soil conserved in different treatments. 
Citation: Subudhi R (2013) Effect of Conservation Trenches on Plantation Crop in Degraded Watershed in Kandhamal District of Odisha. Agrotechnol 2: 112. doi:10.4172/2168-9881.1000112

Page 3 of 3

It can be concluded that $10 \mathrm{~m}$ CCVD should be recommended for upland of degraded watershed of Kandhamal district of Orissa.

\section{Acknowledgement}

The authors acknowledge the help of Vice Chancellor, O.U.A.T., Director, CRIDA, Hyderabad and Dean of Research. O.U.A.T., Bhubaneswar, for timeto-time guidance and financial help to carry out this project. The authors also acknowledge the help of D.L.A.P. staff of Phulbani and staff of CAET, OUAT, Bhubaneswar, who are helping for the success of the project.

\section{References}

1. Samra JS (2002) Watershed management a tool for sustainable production Proceedings of Indian Association of Soil \& Water Conservationists, Dehradun conference held in 20011-10.
2. Subudhi CR, Pradhan PC, Senapati PC (1999) Effect of grass bund on erosion loss and yield of rainfed rice, Orissa, India, T.Vetiver Network 19:32-33.

3. Arora D, Gupta AK (2002) Effect of water conservation measures in a pasture on the productivity of Buffel grass. Proceedings of Indian Association of Soil \& Water Conservationists, Dehradun conference held in 2001 65-66.

4. Kumar M (2002) Impact of soil \& water conservation on erosion loss and yield of Kharif crops under ravenous watershed. Proceedins of Indian Association of Soil \& Water Conservationists, Dehradun conference held in 2001301 303.

5. Annonymous (2003) Final progress report of NATP, RRPS-7, DLAP, OUAT, Phulbani.

6. Patil PP, Gutal GB, Ganvir BN, Bodake PS (2004) Soil and moisture conservation practices for the hill slopes in Western Ghat of Maharastra. Extended abstracts of National Conferences on Resource Conserving Technologies for Social Upliftment. 122-124. 